\title{
Software Compare and Contrast: Blackboard, WebCT and Lotus Notes a Panel Discussion
}

\author{
Barbara Lewis, \\ University of South Florida, \\ FL, USA
} blewis@admin.ust.edu

\author{
Virginia MacEntee and Pam Youngs-Maher, \\ SUNY Oswego, \\ Oswego, NY, USA
}

\begin{abstract}
With the introduction of the World Wide Web, the learning environment is changing. Online courses allow learners, once bound by place and time constraints in the traditional classroom, new access to education and collaborative learning. Technology enables this method of delivering education. Selection of technology and software needs to be based on the needs and objectives of the online programs and the students. The instructor needs components that will allow him/her to create active learning experiences in the courses. This investigation evaluated three Course Management Software programs based on each one's ability to accommodate different active learning experiences in online courses.
\end{abstract}

Keywords: Active Learning, Online Learning, Course Management Software, WebCT, Blackboard, Lotus Notes Domino Server

\section{Introduction}

This paper will evaluate three Course Management Software programs based on each one's ability to accommodate different active learning experiences in online courses. The CMS programs are WebCT, v.3.6; BlackBoard, v. 4; and Lotus Notes, v.4.6. The comparison will be built upon faculty and student perspectives; infrequent references will be made to software administration.

In choosing and using any type of courseware, an instructor needs to have components that will allow the instructor to create active learning courses. Active Learning is defined as any teaching method "that involves students in doing things and thinking about the things they are doing" (Bonwell \& Eison, 1991). Bednar, Cunningham, Duffy, and Perry (1993) state that learning is an active process in which meaning is developed on the basis of experience. In an online course, students need the active learning to feel they are part of the course rather than a loner out in cyber world. It connects the student to other students in the course.

Students who take on-line courses tend to be self-directed learners. They show initiative, independence, and persistence in learning. As they accept respon-

Material published as part of these proceedings, either on-line or in print, is copyrighted by Informing Science. Permission to make digital or paper copy of part or all of these works for personal or classroom use is granted without fee provided that the copies are not made or distributed for profit or commercial advantage AND that copies 1) bear this notice in full and 2) give the full citation on the first page. It is permissible to abstract these works so long as credit is given. To copy in all other cases or to republish or to post on a server or to redistribute to lists requires specific permission from the publisher at Publisher@intormingscience.org sibility for their learning, they see problems as challenges rather than obstacles. They share a high degree of curiosity, a strong desire to learn, and the capacity for self-discipline. They can set goals, make plans, organize their time, and set an appropriate pace for learning. 
Each participant finds outside, related articles on the Internet; reads, summarizes, and critiques the article. Other participants can choose to access the article themselves, and/or comment on their classmate's critique. Students can then comment on other people's comments. A lot of valid information can come from this activity.

\section{Benefits of online courses:}

- They allow students to choose what to focus on and to take control of their own learning experience.

- The number of articles and amount of information that students can access is unlimited.

- They brings outside resources into the course.

- They provide participants with an extensive list of summaries of related resources that they can choose to read, or archive for later use.

Students are learning and practicing research skills--searching, summarizing, and demonstrating what has been learned, integrating new information into knowledge learned previously. These active learning skills that are developed and enhanced through online education will serve these students throughout their lifetime.

\section{Courseware}

\section{WebCT}

WebCT is used in more than 2,500 institutions in 81 countries around the world and is available in 10 major world languages (WebCT, 2002).

WebCT's strategy is to deliver the best-of-breed learning tools, robust content management capabilities, dynamic learning information management, enhanced learning personalization, enterprise-class architecture, and strategic implementation services that institutions will need to compete effectively, today and years from now. (WebCT, 2002).

WebCT is an icon driven software tool. Faculty link html documents, PowerPoint presentations or URLs to icons so that students click to read the material. They can also link several html documents together and WebCT builds a table of contents for the documents. Faculty can create organizer pages for modules or even resources. They have the option of customizing the layout by modifying headers, footers, navigation menus, and color schemes throughout their courses. Faculty can customize banners, backgrounds, and images by uploading them into the course making a course or set of courses completely unique. Typical assessment methods used in determining learning outcomes include tests made up of short answer, multiple choice, True/False or combinations of all three; surveys and self-tests. WebCT accommodates text, graphics and audio and video mediums by storing them in a file manager in which faculty can organize and retrieve documents.

\section{Blackboard}

Blackboard courseware brings added value to traditional education. It was founded in June 1997 and has grown to serve many of the largest, innovative, and best-known institutions. The advantages of online education have made a significant impact in higher education today and, as technology evolves, promise to deliver even greater benefits in the future. Blackboard builds on the belief that effective use of course management tools plays an integral part in developing quality online education (Yaskin, D. \& Gilfus, S. 2001). 
A Blackboard course consists of a navigation path, a button bar and content frames. Faculty type or upload their course materials into Blackboard. Blackboard can accommodate text, graphics and audio mediums. The course material does not have to be html documents. Faculty can load Word documents or even PowerPoint presentations. The navigation path allows users to return to any page accessed between the main course page and the current pages. The button bar links users to the available content areas and tools. The content frame displays web pages accessed through the button or navigation path. Typical assessment methods used in determining learning outcomes include tests made up of short answer, multiple choice, True/False or combinations of all three.

\section{Lotus Notes}

Lotus Notes is a database system. Used for the foundation of the asynchronous system built by the SUNY Learning Network, it provides faculty with the option of a pre-designed template or creating template. The software is very similar to programs most faculty are familiar with on their computers. The software accommodates text, graphics, audio and video mediums. It allows for individual as well as small and large

group assignments. Typical assessment methods used in determining learning outcomes include participation in discussions; papers; presentations; tests made up of short answer, multiple choice, True/False or combinations of all three; and self-tests. Lotus Notes has the value added components of multi-media elements, threaded discussions, hotlinks within the course and out to the Internet, the value of archiving an entire course including all faculty and student documents and communications, and access to one's course 24/7 through the web. An advantage of Lotus Notes for the instructor is that all work can be done offline and then uploaded to the web while downloading students' latest submissions.

\section{Design and Delivery of Online Courses}

\section{Content Development}

Instructors develop and deliver content based on learning outcomes and objectives. What is it the student is to accomplish at the end of the semester, the end of the program, in five years? A careful balance of curriculum outcomes and technology guides the development of the online course. An online learning community is built by the instructor through the creation of learning activities that promote interaction with the content, with the instructor, and between the learners in the class. Effective online education is not centered on technology, but rather on a meaningful learning process. In the online environment, the students and the instructor collaborate to create a dynamic learning experience.

The curriculum in an online course, and an online program, must be designed deliberately with the collaborative, interactive elements built in. Course content should be organized in modules with clear deadlines for the assigned work in each cluster of content and learning activities in order to move students through the course as a cadre of learners. Lectures should be distilled and imbedded with visuals, openended remarks that elicit comments and viewpoints, and with hotlinks to sites on the WWW to make them interactive. Learning activities should include clear assignments with simplified instructions. The online curriculum should focus on higher-level learning (critical thinking, assessment and evaluation, application to the real world, and synthesis across the curriculum) and provide opportunities for the exchange and critique of ideas among students and with the instructor.

Technology is a means of delivering education. The technology should be selected based on the needs and the objectives of the online programs. It must be user friendly, reliable, accessible, and affordable. Technical support is absolutely critical to the success of an online course. 
Software Compare and Contrast

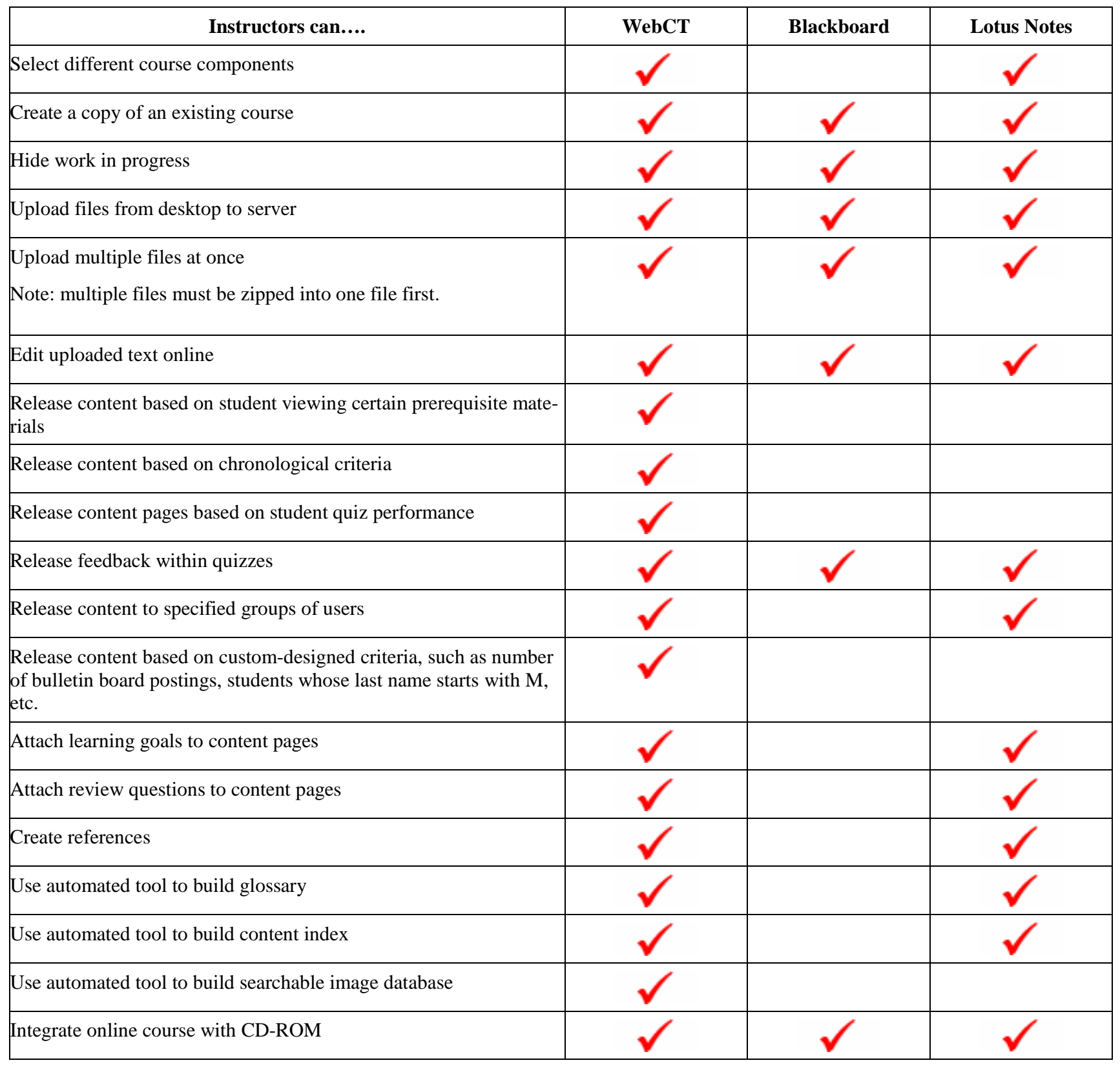

(Adapted from: Boston University, 2002)

Table 1: Content Development

\section{Bulletin Boards/Discussion Area}

The Bulletin Board/Discussion Area is a highly interactive learning environment. The online format allows for a high level of interaction between the students and the instructor and among the students themselves. Students access the lecture materials, assignments and readings and then interact with fellow students and the instructor through focused, facilitated discussions. Students must actively seek out the required material. They collect information and send it to the discussion board for comments, critiques and more discussion. Since the construction of their correspondence is not limited by time, students can take as much time as they need. This breaking of real-time constraints allows for a more thoughtful conversation, since they can ponder what they have to say, and use the full editing power of a word processor. Ideas are shared as each individual contributes to the course discussions and comments on the work of others. Continuous synergy is generated through this active learning process. 
The instructor must create an atmosphere of collaborative teamwork. Students will depend on one another for a large portion of their learning. The instructor needs to know how to work as part of this team as well as help the students work with each other. Questions must be constructed at the targeted cognitive level, must be consistent with the instructional purpose and must be open-ended. Setting the agenda and providing leadership and direction without controlling the class are cornerstones to facilitating the online discussion. There must be a balance between leading the group and creating an environment where students themselves meet the learning objectives. The leadership model becomes one of dynamic facilitation, which is a shift away from an authoritarian style toward a more democratic style

\begin{tabular}{|c|c|c|c|}
\hline Feature & WebCT & Blackboard & Lotus Notes \\
\hline $\begin{array}{l}\text { Multiple bulletin boards or discussion areas per } \\
\text { course }\end{array}$ & & & \\
\hline Private bulletin board/ discussion for each group & & & \\
\hline Instructors can allow anonymous postings & & & \\
\hline $\begin{array}{l}\text { Instructors can move messages from one area to } \\
\text { another }\end{array}$ & & & \\
\hline Instructors can delete messages & & & \\
\hline Users can mark messages read/unread & & & Faculty only \\
\hline $\begin{array}{l}\text { Users can view messages based on read/unread } \\
\text { status }\end{array}$ & & & $\begin{array}{c}\text { Vaculty only } \\
\text { Fa }\end{array}$ \\
\hline $\begin{array}{l}\text { Users can view messages as threaded or un- } \\
\text { threaded }\end{array}$ & & & Threaded only \\
\hline $\begin{array}{l}\text { Users can compile a self-selected set of postings } \\
\text { from bulletin board for their own notes }\end{array}$ & & & \\
\hline $\begin{array}{l}\text { Users receive announcements on login page re: } \\
\text { new postings }\end{array}$ & & & \\
\hline $\begin{array}{l}\text { Users can e-mail posting authors directly from the } \\
\text { bulletin board }\end{array}$ & & & \\
\hline
\end{tabular}

(Adapted from: Boston University, 2002)

Table 2: Bulletin Boards/Discussion Area

\section{Group Participation}

The primary advantage of asynchronous online learning is that it allows students to participate in high quality learning situations when issues of distance and scheduling make on-ground learning inaccessible. Students can participate in classes from anywhere in the world provided they have a computer and Internet connection. Also, the online format allows physically challenged students more flexibility to fully participate in class since the Virtual Classroom is delivered to their home or their work through their computers instead of the students having to physically move to class.

Online learning environments offer several benefits for small group work. It allows small groups to work independently while still having access to the instructor. Factors such as geography, gender, or disabili- 


\begin{tabular}{|l|c|c|c|}
\hline \multicolumn{1}{|c|}{ Feature } & WebCT & Blackboard & Lotus Notes \\
\hline Instructors can create groups manually & $\sqrt{ }$ & \\
\hline $\begin{array}{l}\text { Instructors can have program create groups and } \\
\text { assign members randomly }\end{array}$ & $\sqrt{ }$ & \\
\hline Users can e-mail members of a group & $\sqrt{ }$ & \\
\hline Group members can share files & $\sqrt{ }$ & \\
\hline Group members can have a private chat area & $\sqrt{ }$ & \\
\hline Group members can have private bulletin boards & $\sqrt{ }$ & & \\
\hline $\begin{array}{l}\text { Group members can have Web content presenta- } \\
\text { tion areas }\end{array}$ & $\sqrt{ }$ & & \\
\hline
\end{tabular}

(Adapted from: Boston University, 2002)

\section{Table 3: Group Participation}

ties do not disadvantage learners in this environment. The instructor is able to respond directly to questions and needs of particular groups without impacting other groups.

Online projects give students an opportunity to pursue their special interests and can be done individually or within groups. Projects also provide students with practical experience and a sense of accomplishment. Using projects in a learning activity makes the learning more relevant to the learners. Projects can be shared with others in the class. When sharing individual projects with other participants, the learner has the opportunity to obtain more diverse viewpoints and feedback.

Students are able to participate in the classroom as members of a learning community within all three software programs. They are able to view the profiles or homepages of fellow students in the virtual class, experience online discussions that are unbounded by time and therefore allow students to participate who might not otherwise contribute in the traditional classroom. Indeed, most online instructors will build in a significant percentage of a student's grade on one's participation in the online discussions (most

\begin{tabular}{|l|c|c|c|}
\hline \multicolumn{1}{|c|}{ Feature } & WebCT & Blackboard & Lotus Notes \\
\hline $\begin{array}{l}\text { Calendar on login page displays events from all } \\
\text { courses }\end{array}$ & & $\sqrt{ }$ \\
\hline $\begin{array}{l}\text { Announcements from all courses display on login } \\
\text { page }\end{array}$ & $\sqrt{ }$ & $\begin{array}{c} \\
\text { to a schedule }\end{array}$ \\
\hline $\begin{array}{l}\text { Instructor can upload multiple events from a file } \\
\text { in a schedule }\end{array}$ & $\sqrt{ }$ \\
\hline $\begin{array}{l}\text { Instructor can add links to calendar entries } \\
\text { instructor's discretion) }\end{array}$ & $\sqrt{ }$ & & \\
\hline
\end{tabular}

(Adapted from: Boston University, 2002)

Table 4: Calendar 
often quality and quantity of postings). This serves as an incentive to participate. Because students do have time to reflect on discussions in an asynchronous course, their participation should demonstrate that analysis and synthesis of the information has resulted in a higher level of cognitive and affective knowledge and skills.

\section{Calendar}

The calendar plays an important role in keeping students apprised of course deadlines. It can be printed out and kept handy for continuous access. It serves faculty and students alike as an advance organizer.

\section{Chat/Whiteboard/E-mail}

The professor can create synchronous chat rooms, which can be used for office hour type questions and answer forums. The chat room can also be used to hold "live" classroom discussions or to allow guest speakers to talk with the class. Whiteboard space can be used to display web pages. E-mail provides a quick method to contact course participants.

\section{Student Study Tools}

Various software programs provide different tools for students to use. Additionally, each faculty member or instructor will choose tools based on the learning outcomes for the course and the needs of the learners. All three software programs featured here allow students repeated access to lecture notes or study guides

\begin{tabular}{|l|c|c|c|}
\hline \multicolumn{1}{|c|}{ Feature } & WebCT & Blackboard & Lotus Notes \\
\hline $\begin{array}{l}\text { External e-mail (accessible through regular e- } \\
\text { mail client) }\end{array}$ & & $\sqrt{ }$ & Faculty \\
\hline Internal e-mail (with forwarding capabilities) & $\sqrt{ }$ & \\
\hline Chat transcripts/logs & $\sqrt{ }$ & \\
\hline Multiple chat rooms in a single course & $\sqrt{ }$ & \\
\hline Restricted access to group chat rooms & & & \\
\hline Private messaging in chat & & & \\
\hline $\begin{array}{l}\text { Ring in chat (to notify another user you want to } \\
\text { chat with them) }\end{array}$ & & & \\
\hline $\begin{array}{l}\text { Alert in chat (receive notification when someone } \\
\text { enters the chat room) }\end{array}$ & $\sqrt{ }$ & \\
\hline Whiteboard facility & $\sqrt{ }$ & & \\
\hline Access whiteboard through chat only & & & \\
\hline Save whiteboard images into course content & $\sqrt{ }$ & \\
\hline Export whiteboard images & & & \\
\hline Chat program type & & & \\
\hline Aava & & & \\
\hline
\end{tabular}

(Adapted from: Boston University, 2002)

Table 5: Chat/Whiteboard/E-mail 


\begin{tabular}{|l|c|c|c|}
\hline \multicolumn{1}{|c|}{ Students Can... } & WebCT & Blackboard & Lotus Notes \\
\hline Create study guide & $\checkmark$ & & \\
\hline $\begin{array}{l}\text { Resume reading content at previous stop- } \\
\text { ping point }\end{array}$ & $\checkmark$ & & \\
\hline Add notes on course content Web page & $\checkmark$ & & $\checkmark$ \\
\hline Take notes in an internal notepad & $\checkmark$ & $\checkmark$ & \\
\hline Compile a set of e-mail messages & $\checkmark$ & & \\
\hline Compile a set of bulletin-board postings & $\checkmark$ & $\checkmark$ & \\
\hline Take self-tests created by the instructor & $\checkmark$ & & $\checkmark$ \\
\hline Search course material & $\checkmark$ & & \\
\hline Create original content on own Web pages & $\checkmark$ & $\checkmark$ & \\
\hline
\end{tabular}

(Adapted from: Boston University, 2002)

\section{Table 6: Student Tools}

that faculty create; some of the software allows students to create study guides. Frequent and unrestricted access to lecture notes or content overviews can be a huge benefit of online learning for students who need multiple episodes of exposure to material to develop strong comprehension of the information. Those who are visual learners, who have learning disabilities or who know English as a Second Language (ESL students) all benefit from having access to lectures online.

Additionally, online discussions also serve as study tools. Often the discussions create the place for students to examine concepts, analyze theories, evaluate the information, or assess the information from the perspective of other students and the instructor. The online discussion is archived and easily referred to at a later date in order to study for further reflection or for assignments that build on the discussions.

\begin{tabular}{|l|c|c|c|}
\hline \multicolumn{1}{|c|}{ Feature } & WebCT & Blackboard & Lotus Notes \\
\hline Embed RealPlayer in pages & $\checkmark$ & $\checkmark$ & $\checkmark$ \\
\hline Embed MP3 in pages & $\checkmark$ & $\checkmark$ & \\
\hline Embed QuickTime player in pages & $\checkmark$ & $\checkmark$ & \\
\hline $\begin{array}{l}\text { Add audio and video content that is } \\
\text { stored within the courseware product }\end{array}$ & $\checkmark$ & $\checkmark$ & $\checkmark$ \\
\hline $\begin{array}{l}\text { Add streaming PowerPoint presenta- } \\
\text { tions created with RealVideo, RealPre- } \\
\text { senter, Window Media Encoder }\end{array}$ & $\checkmark$ & $\checkmark$ & \\
\hline
\end{tabular}

(Adapted from: Boston University, 2002)

\section{Table 7: Audio/Video}




\begin{tabular}{|l|c|c|c|}
\hline \multicolumn{1}{|c|}{ Feature } & WebCT & Blackboard & Lotus Notes \\
\hline $\begin{array}{l}\text { Instructors can view number of hits per } \\
\text { page }\end{array}$ & $\sqrt{ }$ & \\
\hline $\begin{array}{l}\text { Instructors can view date and time of } \\
\text { each student's first and last login }\end{array}$ & $\sqrt{ }$ & & \\
\hline $\begin{array}{l}\text { Instructors can view a complete history } \\
\text { of each student's time spent online in } \\
\text { the entire course }\end{array}$ & $\sqrt{ }$ & & \\
\hline $\begin{array}{l}\text { Instructors can view a graphic break- } \\
\text { down of the percent of total time online } \\
\text { each student has spent on each page of } \\
\text { content }\end{array}$ & & & \\
\hline $\begin{array}{l}\text { Instructors can view a graphic break- } \\
\text { down of the percent of total time online } \\
\text { each student has spent on content areas }\end{array}$ & & & \\
\hline
\end{tabular}

(Adapted from: Boston University, 2002)

\section{Table 8: Monitoring Student Participation and Progress}

\section{Audio/Video}

The ability to listen to sound bytes and watch movie clips enhances course content. The audio component in a course helps an auditory learner and the video component in the course helps a visual learner access the course content.

\begin{tabular}{|l|c|c|c|}
\hline \multicolumn{1}{|c|}{ Feature } & WebCT & Blackboard & Lotus Notes \\
\hline $\begin{array}{l}\text { Instructors can analyze the class by } \\
\text { combinations of information, such as } \\
\text { students who logged in after a certain } \\
\text { day and have posted a certain number } \\
\text { of articles }\end{array}$ & $\checkmark$ & & \\
\hline $\begin{array}{l}\text { Instructors can view how many bulletin } \\
\text { board articles a student has read }\end{array}$ & $\checkmark$ & & \\
\hline $\begin{array}{l}\text { Instructors can view how many bulletin } \\
\text { board articles a student has posted }\end{array}$ & $\checkmark$ & & \\
\hline $\begin{array}{l}\text { Instructors can view a transcript of } \\
\text { course chat room activity/discussion }\end{array}$ & $\checkmark$ & $\checkmark$ & $\checkmark$ \\
\hline Student can view own grades & $\checkmark$ & & \\
\hline $\begin{array}{l}\text { Student can compare own grade to } \\
\text { class summary data }\end{array}$ & $\checkmark$ & & \\
\hline
\end{tabular}

(Adapted from: Boston University, 2002)

Table 9: Monitoring Student Participation and Progress 


\begin{tabular}{|c|c|c|c|}
\hline Feature & WebCT & Blackboard & Lotus Notes \\
\hline $\begin{array}{l}\text { Gateway page allows users to view all courses } \\
\text { in which they are enrolled }\end{array}$ & & & \\
\hline $\begin{array}{l}\text { Instructor can change page design globally } \\
\text { during course design }\end{array}$ & & & \\
\hline $\begin{array}{l}\text { Courseware product defaults to graphic inter- } \\
\text { face }\end{array}$ & & & \\
\hline $\begin{array}{l}\text { Courseware product automatically generates } \\
\text { header and footer on new pages }\end{array}$ & & & \\
\hline $\begin{array}{l}\text { Courseware product provides multiple icon } \\
\text { and button styles }\end{array}$ & & & \\
\hline $\begin{array}{l}\text { Instructor can substitute buttons or icons of } \\
\text { own design }\end{array}$ & & & \\
\hline $\begin{array}{l}\text { Instructor can specify a customized course } \\
\text { banner }\end{array}$ & & & \\
\hline $\begin{array}{l}\text { Instructor can select a custom background } \\
\text { color or graphic }\end{array}$ & & & \\
\hline $\begin{array}{l}\text { Courseware product can display components } \\
\text { of the interface in a language other than Eng- } \\
\text { lish (in student-view only) }\end{array}$ & & & \\
\hline Users can view course map & & v & \\
\hline Users can search course content & & & \\
\hline
\end{tabular}

(Adapted from: Boston University, 2002)

Table 10: Navigation and Interface

\section{Monitoring Student Participation and Progress}

Each CMS provides different tools for faculty to manage their course. In Lotus Notes for example, faculty are able to view the dates of all students' submissions and can determine in what area of the course the participation occurred (i.e. in Module 1, discussion or Module 4, assignment or test). It shows all student work, all evaluations, and the scores from each evaluation, and the number of times a student has participated in each discussion. In Blackboard, instructors are able to view the percentage of times that students went to course material; they cannot view time stamps on certain content pages. WebCT is able to monitor student progress throughout the course. Instructors are able to view dates and times that students accessed content pages.

In both Blackboard and Lotus Notes, students are able to view all their own grades, but are not able to compare their performance with their peers unless the instructor creates a spreadsheet with that data. In WebCT, an instructor can automatically set up the grades to compare performance among students.

\section{Navigation and Interface}




\begin{tabular}{|c|c|c|c|}
\hline Feature & WebCT & Blackboard & Lotus Notes \\
\hline Users log in with password and login name & & & \\
\hline $\begin{array}{l}\text { Administrators and instructors can assign mul- } \\
\text { tiple instructors to a course }\end{array}$ & & & \\
\hline $\begin{array}{l}\text { Administrators can create system-wide accounts } \\
\text { (for example, within multiple courses) }\end{array}$ & & & $\sqrt{ }$ \\
\hline $\begin{array}{l}\text { Instructors can automatically upload class roster } \\
\text { files }\end{array}$ & $\boldsymbol{V}$ & $\sqrt{ }$ & \\
\hline
\end{tabular}

(Adapted from: Boston University, 2002)

\section{Table 11: Site Administration}

Navigation and interfacing with Blackboard and Lotus Notes depends on whether you view the CMS from the instructor or the student perspective. In WebCT, the interface view is the same for student or instructor. To add or create content, quizzes, discussions questions, the instructor in WebCT clicks on designer options. Blackboard is very faculty friendly, but very challenging for students to navigate. Students must learn by trial and error what is behind each button, and often it is not intuitive. WebCT and Lotus Notes, on the other hand, are more challenging for faculty to learn to use, but are very student friendly. In Blackboard and Lotus Notes, a student can go to a course map that shows on one page all the documents in the syllabus, one hotlink to the Bulletin Board, one hotlink to one's evaluations. In Lotus Notes, there is one hotlink to each module (i.e. cluster of lectures and learning activities for each unit of content). Once the student clicks on the hotlink for the module, all the lectures, discussions, and assignments, as well as a question area appear in one menu. WebCT and Lotus Notes icons help guide students to discussions and assignments, to the question area, back to the course map or to the module menu, as well as to previous and subsequent documents. In Lotus Notes, the instructor controls the module menu but all icons and course map layout are determined at the system administration level in order to ensure consistency across the SUNY system and for ease in student access and in technical support. However, in WebCT the instructor can choose a course package setup or create one's own course layout.

\section{Site Administration}

\section{Summary}

All three CMS packages provide online learning experiences for students who might not otherwise be able to access such courses or programs. While each one has some unique features, there are several common elements. WebCT, Blackboard and Lotus Notes all allow for asynchronous access to one's courses 24 hours a day $/ 7$ days a week. They all provide tools for students to participate in discussions and small group activities; share files; communicate asynchronously; and read, review and reflect upon interactive text materials with audio and visual enhancements (repeatedly!). WebCT and Blackboard also offer the value added components of synchronous communication through chat and whiteboard sessions. WebCT offers many course management features. Blackboard offers a considerable number of course management functions, and Lotus Notes has many helpful management tools but offers the fewest options. The selection of what CMS to work with will often be based on price, technical support needed, learning curve for faculty, and ease of use for students. Selection of software based on specific components may drive some institutions, while others simply see tradeoffs. 


\begin{tabular}{|c|c|c|c|}
\hline Feature & WebCT & Blackboard & Lotus Notes \\
\hline Instructors can create groups & & & \\
\hline Course controls are on a separate page & & & \\
\hline Course controls are integrated with student view & $\sqrt{7}$ & & \\
\hline $\begin{array}{l}\text { Users can navigate with a consistent, logical } \\
\text { user interface }\end{array}$ & & & \\
\hline $\begin{array}{l}\text { Navigational trail shows the path taken to a par- } \\
\text { ticular screen }\end{array}$ & & & \\
\hline $\begin{array}{l}\text { Instructors can create an unlimited amount of } \\
\text { course content }\end{array}$ & & & \\
\hline $\begin{array}{l}\text { Instructors can upload and create folders and } \\
\text { upload files into a file manager }\end{array}$ & & & \\
\hline Instructors can back up course content & & & \\
\hline Users can search the on-line manual & & & \\
\hline On-line help is context sensitive & & & \\
\hline Users can print .pdf versions of the manuals & & & \\
\hline Users can log out without exiting their browser & & & \\
\hline
\end{tabular}

(Adapted from: Boston University, 2002)

\section{Table 12: Site Administration}

Ultimately, once the CMS system is chosen, faculty develop courses that cultivate active learners who will in turn utilize those skills over a lifetime. While various CMS systems differ in the features they offer, effective online education provides instructors with a fresh opportunity to assess how one teaches, how one learns, and often helps enhance education across mediums and miles.

\section{References}

Bednar, A.K., Cunningham, D., Duffy, T.M., \& Perry, J.D. (1993). Theory into practice: How do we link? In G. Anglin (Ed.), Instructional technology: Past, present, and future. Denver, CO: Libraries Unlimited.

Bonwell, C., \& Eison, J. (1991). Active learning: Creating excitement in the classroom (ASHE-ERIC Higher Education Report No. 1). Washington, DC: George Washington University, p. 2

Boston University (2002). Comparison of WebCT, Blackboard, and Prometheus. Retrieved February 23, 2002 from the World Wide Web http://software2.bu.edu/webcentral/research/courseware/

WebCT, Inc. (2002). About Us. Retrieved February 23, 2002 from the World Wide Web http://www.webct.com/company

Yaskin, D \& Gilfus, S. (2001). Blackboard 5: Introducing the Blackboard 5 Learning System. White Paper. November 29, 2001 Retrieved February 23, 2002 from the World Wide Web http://company.blackboard.com/docs/cp/orientation/EnterpriseLearningWhitePaper.pdf. 


\section{Biography}

\section{Barbara Lewis: WebCT}

Barbara Lewis is an Instructional Designer at the University of South Florida. She works with faculty designing and developing online courses using both WebCT and Blackboard. She is also an adjunct faculty teaching web-enhanced technology course at University of South Florida. Barbara has been creating online courses for the last four years in the university setting. Prior to working in academia, she was an instructional design consultant within the corporate environment.

\section{Virginia MacEntee: Blackboard}

Virginia is currently a professor at SUNY Oswego teaching in the Master Program for Special Education. She has designed and taught two online course for the SUNY Learning Network. Concurrently, Virginia is also an adjunct professor at San Diego State teaching Special Education courses online. She is currently designing and teaching online courses in both Blackboard and Lotus Notes.

\section{Pam Youngs-Maher: Lotus Notes}

Pam is Assistant Director of Continuing Education/Instructional Designer at SUNY Oswego. She assists faculty in the development and management of their online courses utilizing Lotus Notes 4.6 with delivery through the SUNY Learning Network (SLN), an asynchronous delivery system that encompasses 54 of 64 campuses in the statewide SUNY system. Pam also works with key partners who support online courses (library, Instructional Technology, the Center for Excellence in Learning and Teaching, Office of Learning Services) and assists in forming policies and procedures for online education at SUNY Oswego. 